\title{
lodine isotopes (129I and 127I) in the hydrosphere of Qinghai-Tibet region and South
} China Sea

\author{
Yi, Peng; Chen, Xuegao; Wang, Zixia; Aldahan, Ala; Hou, Xiaolin; Yu, Zhongbo
}

Published in:

Journal of Environmental Radioactivity

Link to article, DOI:

10.1016/j.jenvrad.2018.06.005

Publication date:

2018

Document Version

Peer reviewed version

Link back to DTU Orbit

Citation (APA):
Yi, P., Chen, X., Wang, Z., Aldahan, A., Hou, X., \& Yu, Z. (2018). lodine isotopes $\left({ }^{129}\right.$ I and $^{127}$ I) in the hydrosphere of Qinghai-Tibet region and South China Sea. Journal of Environmental Radioactivity, 192, 86-94. https://doi.org/10.1016/j.jenvrad.2018.06.005

\section{General rights}

Copyright and moral rights for the publications made accessible in the public portal are retained by the authors and/or other copyright owners and it is a condition of accessing publications that users recognise and abide by the legal requirements associated with these rights.

- Users may download and print one copy of any publication from the public portal for the purpose of private study or research.

- You may not further distribute the material or use it for any profit-making activity or commercial gain

- You may freely distribute the URL identifying the publication in the public portal 
$1 \quad$ Iodine isotopes $\left({ }^{129} \mathrm{I}\right.$ and $\left.{ }^{127} \mathrm{I}\right)$ in the hydrosphere of 


\section{Abstract}

2 The radioactive isotope ${ }^{129} \mathrm{I}$, with a half-life of $1.57 \times 10^{7}$ years, is widely used as a tracer to 3 assess nuclear safety, to track environmental and geological events and to figure out the 4 details of the stable iodine geochemical cycle. This work investigated the ${ }^{129} \mathrm{I}$ and ${ }^{127} \mathrm{I}$

5 distribution in water samples collected from the terrestrial (rivers, lakes and springs) and 6 marine water systems (estuary and sea) in China. The measured ${ }^{129}$ I concentrations of (1$751) \times 10^{6}$ atoms/L and ${ }^{129} \mathrm{I} /{ }^{127}$ I ratios of $(0.03-21) \times 10^{-10}$ shows the variability of ${ }^{129} \mathrm{I}$ level 8 in the water systems. The local permafrost and seasonal frozen environment play a key role 9 in groundwater recharge in the Qinghai-Tibet region, which is reflected in the ${ }^{129} \mathrm{I}$ 10 distribution in surface water. The depth distribution of ${ }^{129} \mathrm{I}$ in the water column of the South 11 China Sea reflects the effluence of different currents. The results also indicate that the 12 hydrosphere of China contains one to three orders of magnitude lower ${ }^{129}$ I concentrations 13 compared to those reported in Europe. Despite the large distance, the European nuclear 14 fuel reprocessing facilities represent the major source of ${ }^{129} \mathrm{I}$ in the hydrosphere of China 15 through atmospheric transport. The contribution of the Fukushima nuclear accident to ${ }^{129} \mathrm{I}$ 16 levels in the hydrosphere of China was negligible.

\section{Keywords}

19 Iodine-129; Hydrosphere; permafrost; Tibet, China Sea; 


\section{$1 \quad$ 1. Introduction}

2 Iodine-129, is a radioisotope of iodine with a half-life of $1.57 \times 10^{7}$ years, that is naturally 3 produced by the spontaneous fission of uranium in the Earth's crust and cosmic-rays 4 induced spallation of xenon in the atmosphere (Aldahan et al., 2007a; He et al., 2013).

5 These processes resulted in a ratio of ${ }^{129} \mathrm{I} /{ }^{127} \mathrm{I}$ in the marine reservoir that was between $2 \times$ $610^{-12}$ and $6 \times 10^{-13}$ (Fabryka-Martin et al., 1985; Kilius et al., 1992). The natural inventory 7 of ${ }^{129} \mathrm{I}$ was estimated to be approximately $230 \mathrm{~kg}$ (Rao and Fehn, 1999), however, this 8 amount is very small compared to recent anthropogenic releases of ${ }^{129}$ I. Major sources of 9 anthropogenic ${ }^{129}$ I include releases from: 1) atmospheric nuclear weapon tests, 2) nuclear 10 accidents, 3) nuclear power plants operation and 4) nuclear fuel reprocessing facilities.

11 Atmospheric nuclear weapons tests in 1945-1980 released about 43-150 kg of ${ }^{129} \mathrm{I}$ (Carter 12 and Moghissi, 1977; Eisenbud and Gesell, 1997a). Nuclear accidents at Chernobyl in 1986 13 released $6.0 \mathrm{~kg}$ of ${ }^{129} \mathrm{I}$ (Aldahan et al., 2007a) and at Fukushima in 2011 about $1.2 \mathrm{~kg}$ of $14{ }^{129} \mathrm{I}$ (Hou et al., 2013). Emission of ${ }^{129} \mathrm{I}$ from the routine operation of nuclear power plants 15 is suggested to be insignificant (Jin et al., 2009; Zhang et al., 2011). Most of anthropogenic

$16{ }^{129} \mathrm{I}$ in the environment has been released from nuclear fuel reprocessing facilities through 17 atmospheric and marine discharges. Besides atmospheric releases (about $400 \mathrm{~kg}$ by 2007), 18 the Sellafield (UK) and La Hague (France) nuclear facilities have discharged about 6500 $19 \mathrm{~kg}{ }^{129} \mathrm{I}$ to the seas (up to 2007)), with an annual discharge of ${ }^{129} \mathrm{I}$ still remaining at a very 20 high level of about $250 \mathrm{~kg} / \mathrm{y}$ (Liu et al., 2016a). This ${ }^{129} \mathrm{I}$ has contaminated large areas via 21 transport by ocean currents. Furthermore, the re-emission of the reprocessing derived ${ }^{129} \mathrm{I}$ 22 from the contaminated seawater (about 3\% of the marine discharges) to the atmosphere has 23 become an additional source of ${ }^{129}$ I to the atmosphere in recent years (Zhang et al., 2016).

24 Despite the large amount of ${ }^{129} \mathrm{I}$ in the environment, direct health hazards are minimal 25 owing to its low specific radioactivity (long half-life) ( $\mathrm{Li}$ et al., 2005). The criteria of the 26 long half-life have, however, strengthened the use of ${ }^{129} \mathrm{I}$ as environmental tracer of both 27 environmental processes and anthropogenic activities.

29 There has been many published data on the ${ }^{129} \mathrm{I}$ distribution in different Earth reservoirs 30 (atmosphere, hydrosphere, biosphere and soil and sediments) portraying a general picture 
31 of ${ }^{129}$ I contamination and sources in Europe and USA, but such research is meager in China.

32 Some investigations have been performed in selected areas (Hou et al., 2000; Li et al.,

33 2005; Zhou et al., 2010; Zhang et al., 2011; Ma et al., 2013; Zhang et al., 2014) such as the

34 analysis of ${ }^{129} \mathrm{I}$ in seaweed from the south coast region of China and human thyroid samples

35 (Hou et al., 2000), as well as grass, seaweed, seawater and pine needles (Li et al., 2005)

36 and local vegetation, soil and precipitation (Zhang et al., 2011). Although these

37 investigations provided valuable data on ${ }^{129} \mathrm{I}$ concentrations, the regional distribution

38 pattern of ${ }^{129} \mathrm{I}$ in China is far from complete. Consequently, further research concerning ${ }^{129} \mathrm{I}$

39 spatial patterns in China is needed to provide a base line for environmental analysis and

40 prediction. In the investigation presented here, we focus on the distribution of ${ }^{129}$ I and ${ }^{127} \mathrm{I}$

41 in some parts of the hydrosphere of China including water samples collected from rivers

42 and lakes in the Qinghai-Tibet region, Yangtze Estuary and South China Sea (SCS). In

43 addition, we explore the sources of ${ }^{129} \mathrm{I}$ in these regions, assess environmental hazards and

44 establish the possibility of using ${ }^{129} \mathrm{I}$ as a chronological indicator. The choice of these water

45 systems is based on the fact that none of them has been analyzed for ${ }^{129} \mathrm{I}$ and that: 1) The

46 Qinghai-Tibet region is the birthplace of the Yellow River, the second-longest river in Asia

47 and the sixth-longest river system in the world, including Gyaring and Ngöring (Sisters)

48 Lakes (Jin et al., 2009). 2) The Yangtze River is the longest river in Asia and the third-

49 longest in the world, and its river basin is home to one-third of the population of China. 3)

50 The South China Sea is a marginal sea that is part of the Pacific Ocean, encompassing an

51 area from the Karimata and Malacca Straits to the Strait of Taiwan of around 3,500,000

52 square kilometers.

54 2. Sampling and Analytical Methods

\section{$55 \quad 2.1$ Sampling and Sites}

56 Sixteen freshwater samples from the inland water system of the Qinghai-Tibet region, and

572 samples from the Yangtze Estuary were collected. A seawater section in the South China

58 Sea with 10 samples covering the depth interval from $0 \mathrm{~m}$ to $3800 \mathrm{~m}$ (Figure 1 and Table

59 1) was also analyzed in this work. The inland water samples were collected during $15^{\text {th }}$ - 
$19^{\text {th }}$ April and $21^{\text {st }}-25^{\text {th }}$ July in 2014 from Qinghai-Tibet region (Figure 1), the source area

61 of the Yellow River (SAYR), in four watersheds, Madoi, Ngöring lake, Chalaping and

62 Maqu. These samples were selected to represent landscapes of three different frozen

63 ground types (discontinuous permafrost and seasonal frozen region, talik, and continuous

64 permafrost region) (Jin et al., 2009) and environmental conditions (details in Figure 2).

65 Among these samples, 6 were collected from rivers, 6 from lakes and 4 from groundwater

66 springs. The water samples of the rivers and lakes were taken from the surface $(0-5 \mathrm{~cm})$,

67 and the spring water was collected from spring discharge points. The seawater depth profile

68 samples were collected in the SCS in June, 2014. The 2 Yangtze estuary water samples

69 were collected in the estuary area of the East China Sea in June, 2014.

\subsection{Methods}

72 The water samples were collected from spring, lake, estuary and sea. However, some of 73 the river water samples contain high amount of suspending material (mud or sand), which

74 was first removed by decantation. The supernatant of these river samples and all other 75 water samples were then filtered through a $0.45 \mu \mathrm{m}$ membrane and stored in a clean 76 polyethylene container for analysis. The analytical methods reported by Zhou et al. (2010) 77 for determination of ${ }^{127} \mathrm{I}$ and ${ }^{129} \mathrm{I}$ in water and sediment samples were used.

78 For ${ }^{129} \mathrm{I}$ measurement, a one liter of water sample was transferred to a beaker, $1.0 \mathrm{mg}{ }^{127} \mathrm{I}$ 79 carrier (prepared from Woodward iodine, with a ${ }^{129} \mathrm{I}^{127} \mathrm{I}$ atomic ratio of $2 \times 10^{-14}$ ) and about $80500 \mathrm{~Bq}$ of ${ }^{125} \mathrm{I}$ were added, and then $\mathrm{K}_{2} \mathrm{~S}_{2} \mathrm{O}_{8}$ was added to a concentration of $30 \mathrm{mg} / \mathrm{g}$, 81 mixed and covered. The sample was digested at $60^{\circ} \mathrm{C}$ for $20 \mathrm{~h}$ on a hotplate to convert all 82 organic iodine to inorganic form. The solution was then transferred to a separation funnel, $833 \mathrm{ml}$ of $1.0 \mathrm{~mol} / \mathrm{L} \mathrm{NaHSO}_{3}$ was added, and then $\mathrm{HNO}_{3}$ was added to lower the sample $\mathrm{pH}$ 84 to 1-2 to convert all iodine to iodide. $\mathrm{CHCl}_{3}$ was added, and then $\mathrm{NaNO}_{2}$ was added to 85 oxidize iodide to $\mathrm{I}_{2}$, which was extracted to $\mathrm{CHCl}_{3}$ phase by shaking. $\mathrm{CHCl}_{3}$ phase was 86 separated and new $\mathrm{CHCl}_{3}$ was added to the aqueous phase to extract the remaining iodine 87 to organic phase. $\mathrm{CHCl}_{3}$ phases were combined and transferred to a new separation funnel. $880.1 \mathrm{~mol} / \mathrm{L} \mathrm{NaHSO}_{3}$ was added to back extract iodine to water phase. This extraction and 89 back-extraction steps were repeated to purify iodine. ${ }^{125} \mathrm{I}$ in the separated solution was 
measured using a NaI detector for calculation of the recovery of iodine during separation

91 (mean recovery: 85-95\%). The separated iodine solution was transferred to a centrifuge

92 tube, $2 \mathrm{ml}$ of $3.0 \mathrm{~mol} / \mathrm{HNO}_{3}$ and $1.0 \mathrm{~mL}$ of $1.0 \mathrm{~mol} / \mathrm{L} \mathrm{AgNO}_{3}$ were added to precipitate

93 iodide as $\mathrm{AgCl}$. The $\mathrm{AgI}$ precipitate was separated by centrifuge, then washed with 3.0

$94 \mathrm{~mol} / \mathrm{L} \mathrm{HNO}_{3}$ and $\mathrm{H}_{2} \mathrm{O}$.

95 Two ${ }^{129}$ I standard solutions were prepared by diluting ${ }^{129}$ I standard solution (NIST-SRM-

$964949 \mathrm{c}$ ) using ${ }^{127}$ I solution that was prepared from low ${ }^{129} \mathrm{I}$ level iodine carrier (Woodward

97 Inc., ${ }^{129} \mathrm{I} /{ }^{127} \mathrm{I}$ ratio $<2 \times 10^{-14}$ ). The ${ }^{129} \mathrm{I} /{ }^{127} \mathrm{I}$ ratios of the standards are $9.954 \times 10^{-12}$ and

$981.138 \times 10^{-10}$, respectively. The ${ }^{129} \mathrm{I}$ standards as AgI for AMS measurement were prepared

99 using above two standard solutions by directly addition $\mathrm{AgNO}_{3}$ to the standard solution

100 after acidified to $\mathrm{pH} 2$ using $\mathrm{HNO}_{3}$ and addition of $\mathrm{KHSO}_{3}$ to convert all iodine to iodide.

101 The prepared AgI precipitate was dried at $70{ }^{\circ} \mathrm{C}$, ground to fine powder mixed with

102 niobium powder (200 mesh) in a mass ratio of 1:5. The mixture was pressed into a copper

103 holder. ${ }^{129} \mathrm{I} /{ }^{127} \mathrm{I}$ ratios in the prepared targets of samples, standards and blanks were

104 measured using 3MV Tandem AMS system in the Xi' an AMS center. ${ }^{5+}$ ions were selected

105 for the measurement. ${ }^{127} \mathrm{I}^{5+}$ was measured as charges with a Faraday cup, while ${ }^{129} \mathrm{I}^{5+}$ was

106 measured with a gas ionization detector. Each sample was measured for 6 cycles, and 5

107 minutes in each cycle.

108 The concentrations of total iodine $\left({ }^{127} \mathrm{I}\right)$ in the filtered water samples were directly

109 measured using ICP-MS. Thermo X Series ${ }^{\mathrm{II}}$ ICP-MS was used under the conditions of hot

110 plasma and $\mathrm{Xt}$ interface. The detection limit for ${ }^{127} \mathrm{I}$ under this condition was calculated to

111 be $0.02 \mathrm{ng} / \mathrm{ml}$.

112 Procedure blanks were prepared with each batch of samples by the same procedure as the

113 samples, to monitor the laboratory background and cross-contamination in period of

114 separation and measurement. The analytical results showed that the ${ }^{129} \mathrm{I} /{ }^{127} \mathrm{I}$ ratios in the

115 procedure blanks $\left(1 \times 10^{-13}\right)$ are 2 orders of magnitude lower than that in the most of

116 samples. The blank value was subtracted from measured ${ }^{129} \mathrm{I} /{ }^{127} \mathrm{I}$ in the samples. 


\subsection{Spatial distribution of iodine isotopes}

121 The ${ }^{127} \mathrm{I}$ and ${ }^{129} \mathrm{I}$ concentrations and ${ }^{129} \mathrm{I} /{ }^{127} \mathrm{I}$ atomic ratios in water samples collected from 122 the Qinghai-Tibet region, Yangtze Estuary and SCS are presented in Table 1. The ${ }^{129} \mathrm{I} /{ }^{127} \mathrm{I}$ 123 ratios in the inland water of the Qinghai-Tibet region range from $0.18-21.34 \times 10^{-10}$ with a 124 mean ratio of $8.04 \times 10^{-10}(\mathrm{n}=16)$, in which a range of $0.80-19.77 \times 10^{-10}$ in the river water, $1250.23-21.34 \times 10^{-10}$ in the lake water, and $0.18-2.40 \times 10^{-10}$ in the spring water. As for ${ }^{129} \mathrm{I}$ 126 concentrations, they span 5.36-42.68 $\times 10^{6}$ atoms $/ \mathrm{L}$ in the river water, 2.04-51.22 $\times 10^{6}$ 127 atoms $/ \mathrm{L}$ in the lake water, and 1.26-4.34 $\times 10^{6}$ atoms $/ \mathrm{L}$ in the spring water. River water 128 samples No. 2, 3 and 6 were collected from the main stream of the Yellow River, while 129 samples No. 1, 4, 5 were collected from the tributaries (Figure 2). The data show that there 130 is no significant difference between the main stream and tributary samples with respect to $131{ }^{127}$ I concentrations. Lake water samples No. 9, 11, 12 collected from a saltwater lake have 132 higher ${ }^{129}$ I concentrations than those water samples collected from a freshwater lake 133 (Figure 1 and Figure 2). The ${ }^{129}$ I concentrations in the spring water generally show the 134 lowest value compared to the river and lake water in Qinghai-Tibet region, except for one 135 lake water sample that had a very low ${ }^{129}$ I concentration.

136 In the South China Sea (SCS), ${ }^{129}$ I concentrations in the upper $1000 \mathrm{~m}$ of the depth profile 137 are higher than those of the deep water (Figure 3). The ${ }^{129}$ I concentrations steeply decreased 138 in the depth from $1000 \mathrm{~m}$ to $2000 \mathrm{~m}$. At depths below $2000 \mathrm{~m}$, the ${ }^{129} \mathrm{I}$ concentration slightly 139 increases to $3.16 \times 10^{6}$ atoms $/ \mathrm{L}$ at depth of $3000 \mathrm{~m}$, but the concentration drops again below $1403000 \mathrm{~m}$. At the depth of $3800 \mathrm{~m}$, the concentration of ${ }^{129} \mathrm{I}$ is extremely low $\left(0.99 \times 10^{6}\right.$ 141 atoms $/ \mathrm{L}$ ), corresponding to a ${ }^{129} \mathrm{I} /{ }^{127} \mathrm{I}$ ratio of $0.03 \times 10^{-10}$. The trend of ${ }^{129} \mathrm{I}$ concentrations 142 against depth is like that of ${ }^{129} \mathrm{I} /{ }^{127} \mathrm{I}$ ratio, but an inverse trend is observed for the ${ }^{127} \mathrm{I}$ 143 concentrations (Figure 3). In the SCS, the lowest ${ }^{127}$ I concentration appears in the surface 144 water, and then gradually increases from $56 \mu \mathrm{g} / \mathrm{L}$ at surface to $68.6 \mu \mathrm{g} / \mathrm{L}$ at $1500 \mathrm{~m}$, then 145 remains relative constant at $65-68 \mu \mathrm{g} / \mathrm{L}$ from $1500-$ to $3800 \mathrm{~m}$. This depth distribution 146 pattern of ${ }^{127} \mathrm{I}$ is comparable with the stratification effect of the ocean current (Liu et al., 147 2016b). The slightly low ${ }^{127}$ I in surface water may be attributed to the dilution of the low

$148{ }^{127}$ I precipitation (Reithmeier et al., 2010) and/or loss of iodine from the surface water by 149 formation and emission of volatile iodine species (He et al., 2013). Overall, the data cluster 150 into three different layers at $0-1000 \mathrm{~m}, 1000-2000 \mathrm{~m}$ and below $2000 \mathrm{~m}$ (Figure 3). 
151 The ${ }^{129}$ I depth profile distribution (Figure 3) at the sampling location in the SCS indicates

152 that the occurrence of 3 different layers might correspond to different water sources at 153 different depths. This is supported by other observations of ocean currents at different 154 depths in the SCS. It was reported that SCS surface water movement is controlled by a 155 strong winter monsoon (Northeast monsoon drift) from November to April, and the weaker 156 summer monsoon (Southeast monsoon drift) from May to August (Figure 4) (Liu et al., 157 2016b). The higher ${ }^{129}$ I concentration in the upper layer $(<1000 \mathrm{~m})$ compared to the deep 158 layer water might be attributable to a higher contribution of anthropogenic ${ }^{129}$ I input 159 through global fallout from 1945-1980 and riverine input from the inland of China (Liu et 160 al., 2016a). The relatively constant distribution of ${ }^{129} \mathrm{I}$ in the upper $1000 \mathrm{~m}$ water may be 161 caused by mixing induced by the summer and winter monsoon (Liu et al., 2016a). The 162 steeply decreasing ${ }^{129} \mathrm{I}$ concentration from $1000 \mathrm{~m}$ to $2000 \mathrm{~m}$ can be attributed to limited 163 transfer of ${ }^{129}$ I from the above water layer. Schink et al. (1995) has proposed that the flux 164 of water mass from the surface to the deep-water inventory is quite small and has essentially 165 no bearing on the vertical distribution and thus leading to little mixing of the upper 1000 $166 \mathrm{~m}$ water with the $1000 \mathrm{~m}$ to $2000 \mathrm{~m}$ deep waters. A southward deep contour current (2000 167 to $2500 \mathrm{~m}$ ) from Luzon Strait along the continental margin off southeast China has been 168 reported (Qu et al., 2006). This water mass, carrying low ${ }^{129}$ I concentration from the Pacific 169 deep water, enters the SCS leading to the low ${ }^{129}$ I level in this layer. The slightly increased $170{ }^{129}$ I level at $3000 \mathrm{~m}$ depth suggests the intrusion of other water masses. One possibility is 171 that a deep cyclonic current below $2400 \mathrm{~m}$ which has been reported in the SCS (Wang et 172 al., 2011), which may bring some high ${ }^{129}$ I surface water from other locations to the deep 173 part of the SCS. This process was also indicated by the distribution of bomb produced $\Delta^{14} \mathrm{C}$ 174 and tritium in nearby East Sea. Activities of radiocarbon decrease from a maximum in the 175 upper mixed layer to $2000 \mathrm{~m}$ depth, increase to a peak value at $2800 \mathrm{~m}$ and then decrease 176 again towards the bottom, which is comparable to the tritium depth distribution (Watanabe 177 et al., 1991; Cooper et al., 2001).

178 The ${ }^{129}$ I concentrations in the two samples collected from the Yangtze Estuary ((17-21) $179 \times 10^{6}$ atoms/L) are higher than those in the surface seawater of the SCS $\left((11-14) \times 10^{6}\right.$ 180 atoms/L). This suggests different sources of ${ }^{129} \mathrm{I}$ in the Yangtze estuary of the ECS and the 181 SCS. ${ }^{129}$ I in the ECS mainly originates from the input of the Yangtze River, while ${ }^{129} \mathrm{I}$ in 
182 the SCS reflects mainly global fallout, and to lesser extent riverine input. In addition to 183 data presented here (Table 1 and Figure 3), reported values of iodine isotopes in the surface 184 water of the East China Sea (ECS) (Liu et al., 2016a) were used to plot the distribution of 185 iodine isotopes in surface water of the ECS (Figure 4).

186 The measured values of iodine isotopes in the SCS and Yangtze River estuary reported 187 here fit well with the distribution of ${ }^{127} \mathrm{I}$ and ${ }^{129} \mathrm{I}$ concentrations and ${ }^{129} \mathrm{I} /{ }^{127} \mathrm{I}$ ratios in the 188 ECS and the water circulation patterns of the SCS (Figure 4d). It has been reported that the 189 Yangtze River water enters the ECS through the Yangtze Estuary where ${ }^{127}$ I concentrations 190 increase seaward, while ${ }^{129}$ I decreases seaward (Figure 4) (Liu et al., 2016a). This feature 191 suggests decoupling of the ${ }^{129} \mathrm{I}$ and ${ }^{127} \mathrm{I}$ in the Yangtze Estuary that is related to different 192 sources of water. The high-level ${ }^{129} \mathrm{I}$ in the fresh water is diluted by the low ${ }^{129}$ I seawater, 193 while the low-level ${ }^{127} \mathrm{I}$ in the riverine water is diluted by the high ${ }^{127} \mathrm{I}$ concentration 194 seawater when the river water enters the sea. The increased ${ }^{129} \mathrm{I}$ concentrations and ${ }^{129} \mathrm{I} /{ }^{127} \mathrm{I}$ 195 ratios from the SCS to the ECS was observed (Figure 4) and might be attributed to the different sources of ${ }^{129} \mathrm{I}$ in the ECS and SCS, and the water mass exchange processes driven by the monsoons in this region. Due to the anthropogenic high ${ }^{129} \mathrm{I}$ deposition in the middle and northern North Hemisphere, the ${ }^{129} \mathrm{I}$ deposition and input from the rivers to the ECS is higher than that in the SCS. The surface currents in the SCS are mainly controlled by the monsoon drift, with the southwest current direction prevailing in summer and the northeast in winter (Daryabor et al., 2016). This pattern results in that the major movement of surface water follows the monsoon's pathways along the northeast direction and providing a monsoon-related mixing process.

204 The results presented above provide a general fingerprinting of the different water types 205 (inland water, estuary water and seawater) with respect to their ${ }^{127} \mathrm{I}$ concentrations and $206{ }^{129} \mathrm{I} /{ }^{127} \mathrm{I}$ ratios (Figure 5). The inland water, namely, the river water, lake water and spring 207 water, tends to have higher ${ }^{129} \mathrm{I} /{ }^{127} \mathrm{I}$ ratios, but lower ${ }^{127} \mathrm{I}$ concentrations, while the seawater 208 tends to have lower ${ }^{129} \mathrm{I} /{ }^{127} \mathrm{I}$ ratios but higher ${ }^{127} \mathrm{I}$ concentrations. The ${ }^{127} \mathrm{I}$ concentrations 209 and ${ }^{129} \mathrm{I} /{ }^{127} \mathrm{I}$ ratios of the estuary water lies between that of inland water and seawater. The 210 data for ${ }^{129} \mathrm{I} /{ }^{127} \mathrm{I}$ versus ${ }^{129} \mathrm{I}$ in the SCS sea water track the correlation line of seawater 211 samples and extend to lower ${ }^{129} \mathrm{I} /{ }^{127} \mathrm{I}$ values. In the terrestrial hydrosphere the iodine data 212 plot along line of the surface and groundwater of Europe and again extend the European 
213 data to a lower ${ }^{129} \mathrm{I} /{ }^{127} \mathrm{I}$ ratios (Figure 6). The same holds for the ${ }^{129} \mathrm{I} /{ }^{127} \mathrm{I}$ versus ${ }^{127} \mathrm{I}$ plot,

214 except for a discrepancy between the ${ }^{127}$ I concentrations in this study and that presented by

215 Michel et al. (2012). The results suggest dominance of the emission from the European

216 NFRPs on the ${ }^{129}$ I global distribution.

\section{$3.2{ }^{129} \mathrm{I}$ in hydrology of permafrost area in Qinghai-Tibet region}

219 The results of ${ }^{129} \mathrm{I}$ in surface water in the Qinghai-Tibet region show relatively higher ${ }^{129} \mathrm{I}$ 220 levels in the main river samples (No. 2, 3, 6) than the tributaries (No. 1, 4, 5). This 221 difference may be attributed to the complex and varied sources of water in the main stream 222 that receives contributions from the Ngöring lake with many small tributaries and sewer 223 water from Madoi Town. These sources are all located within a discontinuous permafrost, 224 seasonally frozen ground and talik (thermokarst lakes) dominated landscape where surface 225 and subsurface water interacts in a complex pattern. Furthermore, the ${ }^{129}$ I concentrations 226 and ${ }^{129} \mathrm{I} /{ }^{127} \mathrm{I}$ ratios of the main river water (sampling site 2 and 6) were identical to the lake 227 water nearby (sampling site No. 9), indicating a common source from the unfrozen 228 wetlands in the area as well as collapsed peatlands (Jin et al., 2009). During warm periods, 229 thawing of active topsoil layer enhances interflow and shallow groundwater discharge 230 increases (Wang et al., 2009). This process enhances the precipitation-coupled transfer of

$231{ }^{129}$ I deposited on the soil surface into the river. Tributaries water samples (No. 1 and 5), 232 which were mainly generated from the melt snow or recent rainfall that contained relatively 233 low ${ }^{129}$ I concentration. The thaw lake water was also characterized by a relatievly high 234 isotopic ratio (sample No 9 in Xingxinghai lake) compared to other lakes. A high ${ }^{129}$ I value 235 of tributary water was also noticed in Chalaping (sample No. 4), where a large number of 236 thaw lakes are developed. Consequently, wetland water may recharge the rivers (Gibson et 237 al., 2016), which may become enriched in ${ }^{129}$ I owing to accumulation in the organic-rich 238 active layer of soil (Herod et al., 2016). The association of iodine with soil organic matters 239 has been suggested by several investigations (Hou et al., 2003; Luo et al., 2013).

240 The ${ }^{129}$ I concentrations $\left((1.2-4.3) \times 10^{6}\right.$ atoms $\left./ \mathrm{L}\right)$ and ${ }^{129} \mathrm{I} /{ }^{127} \mathrm{I}$ ratio $\left((0.2-2.4) \times 10^{-10}\right)$ in the 241 spring water samples (Table 1) is much lower than those in the river and lake water. 242 However, they are higher than the reproted pre-nuclear level $\left(1.5 \times 10^{-12}\right.$ for ${ }^{129} \mathrm{I} /{ }^{127} \mathrm{I}$ ratio $)$ 
243 in the marine system. This trend suggests that spring water in the Qinghai-Tibet region is 244 mainly recharged from deep groundwater that was partly isolated from the modern 245 environment by the permafrost as an impermeable layer (Yang et al., 2016). Fast transport 246 through most surface water reservoirs and isotopic equilibrium characterize naturally 247 produced iodine with a pre-nuclear era concentration of ${ }^{129} \mathrm{I}$ in surface water at $(0.1-2) \times$ $24810^{4}$ atoms/L (Kohman and Edwards, 1966; Fabryka-Martin et al., 1985; Kilius et al., 1992;

249 Rao and Fehn, 1999). The isotopic equilibrium of iodine isotopes in surface reservoirs has 250 been disturbed since the start of the nuclear era activities in the 1940s. Consequently, the 251 concentration of ${ }^{129} \mathrm{I}$ measured in the spring waters is two or three orders of magnitude 252 higher than the pre-nuclear level (Table 1). This fact indicates that the spring water in 253 Qinghai-Tibet region could be young $(<70$ years) or it reflects mixing with groundwater 254 recharged by post-nuclear era precipitation.

\subsection{Sources of ${ }^{129} I$ in the hydrosphere of China}

257 The pre-nuclear ratio of ${ }^{129} \mathrm{I} /{ }^{127} \mathrm{I}$ in the marine environment was estimated to be $1.5 \times 10^{-12}$ 258 (Moran et al., 1998; Schmidt et al., 1998; Fehn et al., 2013). With an average concentration 259 of stable iodine in the SCS of $60 \mu \mathrm{g} / \mathrm{L}$ (Hou et al., 2002), the contribution from natural 260 source would be $<5 \%$ of ${ }^{129} \mathrm{I}$ in the SCS. A pre-nuclear ${ }^{129} \mathrm{I} /{ }^{127}$ I ratio of $2 \times 10^{-11}$ in terrestrial 261 system was estimated by determination of ${ }^{129} \mathrm{I}$ in the soil of China (Fan et al. 2018). 262 Assuming equilibrium of natural ${ }^{129} \mathrm{I}$ and ${ }^{127} \mathrm{I}$ in the soil and terrestrial water in the pre263 nuclear age, the contribution of natural ${ }^{129} \mathrm{I}$ to the most river and lake water in the Qinghai-

264 Tibet region can be negligible. However, for some river and lake water with low ${ }^{129} \mathrm{I} /{ }^{127} \mathrm{I}$ 265 ratio of $(2.3-7.9) \times 10^{-11}$ and all spring water with ${ }^{129} \mathrm{I} /{ }^{127} \mathrm{I}$ ratios of $(1.7-24) \times 10^{-11}$, the 266 natural ${ }^{129}$ I might be the major source.

267 Another source of ${ }^{129}$ I is related to the nuclear weapons tests (NWTs), mostly took place in $268 \quad 1945-1963$ and released 43-150 kg of ${ }^{129}$ I to the environment (Carter and Moghissi, 1977; 269 Chamberlain, 1991; Eisenbud and Gesell, 1997b). As most testing sites were situated at 270 mid-latitudes of the northern hemisphere, atmospheric ${ }^{129}$ I was mainly deposited in the 271 northern hemisphere (Reithmeier et al., 2010; Snyder et al., 2010; He et al., 2013). It has 272 been reported that ${ }^{129}$ I level in rivers in USA was elevated to $1-5 \times 10^{7}$ atoms/L (Moran et 273 al., 2002) as a result of the NWTs. This range is comparable to the values in the rivers of 
274 the Qinghai-Tibet region $\left(0.54-4.27 \times 10^{7}\right.$ atoms $\left./ \mathrm{L}\right)$ and the waters in Yangtze Estuary $275\left(1.77-2.11 \times 10^{7}\right.$ atoms $\left./ \mathrm{L}\right)$. The contribution from NWTs to the SCS is complicated and is 276 associated with a large uncertainty, but an increase to $1.22 \times 10^{6}$ atoms $/ \mathrm{L}$ in surface water 277 due to atmospheric nuclear weapons tests may provide a small contribution of the total 278 measured ${ }^{129} \mathrm{I}$.

279 The Chernobyl accident happened in 1986 and Fukushima accident are two serious nuclear 280 accident in history and released about $6.0 \mathrm{~kg}$ and $1.2 \mathrm{~kg}{ }^{129} \mathrm{I}$ to the environment, 281 respectively (Aldahan et al., 2007a; Hou et al. 2013). Considering that most of ${ }^{129}$ I released 282 from the Chernobyl accident was deposited in Europe, its contribution as a remote source 283 of ${ }^{129} \mathrm{I}$ in the Qinghai-Tibet region is very limited. Measurement of ${ }^{129} \mathrm{I} /{ }^{127} \mathrm{I}$ ratios in river 284 waters in Xi' an region before the Fukushima accident indicated values of 7.4-37.3 $\times 10^{-10}$ 285 (Zhang et al., 2011). The ${ }^{129} \mathrm{I} /{ }^{127} \mathrm{I}$ ratios of $0.8-19.8 \times 10^{-10}$ in the river waters measured in 286 the Qinghai-Tibet region (Table 1) in this work (after the accident) do not show any visible 287 change due to more recent inputs from Fukushima, which indicates that the contribution 288 from the Fukushima accident to the Qinghai-Tibet region is negligible.

289 As of 2017, 36 nuclear power reactors are in operation in China. It was found that surface 290 seawater samples collected at sites with distance of $0.5-10 \mathrm{~km}$ to the outlet of a nuclear 291 power plant in China had ${ }^{129} \mathrm{I} /{ }^{127} \mathrm{I}$ ratios of $\left((5.7-9.5) \times 10^{-10}\right)$, which are similar to values 292 measured in the seawater collected at the discharge outlet (Zhang et al., 2012; Zhang et al., 293 2014). The ${ }^{129} \mathrm{I} /{ }^{127} \mathrm{I}$ ratios $\left((0.8-2.6) \times 10^{-10}\right)$ at other distant sites $(2-7 \mathrm{~km}$ to the outlet $)$ 294 indicated the same levels as of those reported elsewhere in China which are far away from 295 any nuclear facility. These data suggest insignificant ${ }^{129} \mathrm{I}$ discharge from the power plant 296 (He et al., 2011). In addition, there are no reports of ${ }^{129}$ I releases from other NPPs in Asia 297 or other parts of the world. Therefore, the contribution from NPPs to the ${ }^{129}$ I inventory in 298 China is considered negligible.

299 Nuclear fuel reprocessing plants, especially Sellafield (UK) and La Hague (France), have 300 released around $5700 \mathrm{~kg}$ of ${ }^{129} \mathrm{I}$ (up to 2009) to the environment, which account to more 301 than $90 \%$ of ${ }^{129}$ I inventory in the present environment (Aldahan et al., 2007b; He et al., 302 2013). Regions near these nuclear fuel reprocessing plants have shown high ${ }^{129} \mathrm{I}$ 303 concentrations (Figure 7) (Chen et al., 2015). For instance, the reported ${ }^{129}$ I concentrations 304 in precipitation from North Europe reached up to $300 \times 10^{8}$ atoms/L (Aldahan et al., 2009). 
305 Releases of ${ }^{129} \mathrm{I}$ from La Hague and Sellafield to the atmosphere occur via direct 306 atmospheric emission and remission from seawater, resulting in a global-scale 307 contamination. Due to its relatively long atmospheric residence time of 2-3 weeks (Englund 308 et al., 2010; Reithmeier et al., 2010).

309 The source of water to the lakes in the Qinghai region include mainly precipitation with 310 addition of some groundwater. Differentiating the contribution of groundwater to the lakes 311 is neglected here and we consider only ${ }^{129} \mathrm{I}$ signal from precipitation. Most ${ }^{129} \mathrm{I}$ found in 312 lakes of the Qinghai region and Yangtze Estuary originates from precipitation, thus the 313 portion of atmospheric loading that may have been largely sourced from the NFRP's 314 atmospheric emissions and re-emission of mainly the NFRP's marine discharges should be 315 a major source in the lake and river water in Qinghai region. For the SCS, its average ${ }^{129} \mathrm{I}$ 316 concentration is about $6.6 \times 10^{6}$ atoms/L, it is lower than the ${ }^{129} \mathrm{I}$ concentration in the 317 Qinghai-Tibet region $\left(18 \times 10^{6}\right.$ atoms/L) and Yangtze River Estuary $\left(19 \times 10^{6}\right.$ atoms/L). It 318 has been reported that the discharges of ${ }^{129}$ I from the European NFRP has a significant 319 contribution to the ECS through riverine input and directly atmospheric deposition (Liu et 320 al., 2016a). Meanwhile, the NFRP might also contribute to the 129I inventory in the 321 seawater in the SCS. A significant contribution of NFRP to 129I in seawater in the Pacific 322 Ocean and the Japan Sea have also been reported (Suzuki et al., 2010).

\section{$324 \quad 3.4$ Comparison with the global trends}

325 The comparison of our results with other published data (Figure 7) shows that the ${ }^{129} \mathrm{I} /{ }^{127} \mathrm{I}$ 326 ratios measured in the hydrosphere of China are consistent with those observed in other 327 locations in Asia and North America. The ${ }^{129} \mathrm{I} /{ }^{127} \mathrm{I}$ ratio of many rivers shows comparable 328 values, such as $7.7 \times 10^{-10}$ in the Pearl River, $10.7-24.4 \times 10^{-10}$ in the Atchafalaya River 329 (both located at U.S South Coast), and 7.4-37.2 $\times 10^{-10}$ in river water in the Xi'an region, 330 China (Moran and Oktay, 2002; Zhang et al., 2011). However, the ratio in these rivers is

331 1-3 orders of magnitude lower than in those of western Europe, such as $1.84 \times 10^{-8}$ in Rhine 332 River and $1.88 \times 10^{-8}$ in River Thames (Moran and Oktay, 2002; Snyder and Fehn, 2004), 333 where a significant influence from the European NFRPs was received. These distribution 334 patterns follow the trend of global distribution of ${ }^{129} \mathrm{I}$ in the surface environment where 
335 sampling sites near NFRPs tend to have relatively high ${ }^{129}$ I concentrations (around $10^{10}$ $33610^{11}$ atoms $/ \mathrm{L}$ ). At the time, releases from nuclear accident (e.g. Chernobyl and Fukushima 337 accidents) could be highly localized but comparatively negligible when considering the 338 influences on global scale (Nagai et al., 2015; Chen et al., 2016).

\section{4. Conclusion}

341 Based on the results and discussion above, it can be concluded that:

342 1. The ${ }^{129}$ I concentrations in the hydrosphere of China reflect anthropogenic input with 343 varying degrees being more on land hydrological system (rivers and lakes) than in the sea.

344 2. The ${ }^{129} \mathrm{I}$ depth profiles in the SCS reflect distribution pattern largely controlled by 345 monsoon drift in the surface and cyclonic currents at depth.

346 3. Major source of ${ }^{129} \mathrm{I}$ in China is attributed to atmospheric transport from the NFRPs 347 emissions (direct atmospheric emission and re-emission from the marine water) and global 348 fallout of nuclear weapons tests.

349 4. The effect of Fukushima nuclear accident on the ${ }^{129}$ I concentration in the hydrosphere of 350 China is negligible.

\section{Acknowledgements}

353 This research was funded in part by the Special Fund of State Key Laboratory of 354 Hydrology-Water Resources and Hydraulic Engineering [Grant No. 20165042512 and No. 355 20155045612], the Fundamental Research Funds for the Central Universities [Grant No. 356 2017B10314 and No. 2016B04214], and Postgraduate Research \& Practice Innovation 357 Program of Jiangsu Province [Grant No. KYZZ16_0277]. The first two authors contributed 358 equally to this paper and should be considered co-first authors. 
Aldahan, A., Alfimov, V., \& Possnert, G. (2007a). ${ }^{129}$ I anthropogenic budget: major sources and sinks. Applied Geochemistry, 22(3), 606-618.

Aldahan, A., Possnert, G., Alfimov, V., Cato, I., \& Kekli, A. (2007b). Anthropogenic ${ }^{129}$ I in the baltic sea. Nuclear Inst \& Methods in Physics Research B, 259(1), 491-495.

Aldahan, A., Persson, S., Possnert, G., \& Hou, X. L. (2009). Distribution of ${ }^{127}$ I and ${ }^{129}$ I in precipitation at high European latitudes. Geophysical Research Letters, 36(11), $192-$ 200.

Carter, M. W., \& Moghissi, A. A. (1977). Three Decades of Nuclear Testing. Health Physics, 33(1), 55-71.

Chamberlain, A. C. (1991). Radioactive aerosols. Radioactive Aerosols, 51(07), 11-58.

Chen, X. G., Gong, M., Yi, P., Aldahan, A., Yu, Z. B., \& Possnert, G., et al. (2015). Distribution of ${ }^{129} \mathrm{I}$ in terrestrial surface water environments. Nuclear Instruments \& Methods in Physics Research, 361, 604-608.

Chen, X. G., Liu, X., Yi, P., Aldahan, A., Yu, Z. B., \& Chen, L., et al. (2016). Estimation of ${ }^{129} \mathrm{I}$ inventory in the oceans. Journal of Radioanalytical \& Nuclear Chemistry, 308(1), 59-65.

Cooper, L. W., Hong, G. H., Beasley, T. M., \& Grebmeier, J. M. (2001). Iodine-129 concentrations in marginal seas of the north pacific and pacific-influenced waters of the Arctic Ocean. Marine Pollution Bulletin, 42(12), 1347-1356.

Daryabor, F., Ooi, S. H., Samah, A. A., \& Akbari, A. (2016). Dynamics of the water circulations in the southern South China Sea and its seasonal transports. Plos One, 11(7), e0158415.

Eisenbud, M., Gesell, T. (1997a). Chapter 9 - Nuclear Weapons. Environmental Radioactivity, 266-315.

Eisenbud, M., Gesell, T. (1997b). Chapter 6 - Natural Radioactivity. Environmental Radioactivity, 6(3), 134-200.

Englund, E., Aldahan, A., Hou, X. L., Possnert, G., \& Söderström, C. (2010). Iodine ( ${ }^{129}$ I and ${ }^{127}$ I) in aerosols from northern Europe. Nuclear Instruments \& Methods in Physics Research, 268(7-8), 1139-1141.

Fabryka-Martin, J., Bentley, H., Elmore, D., \& Airey, P. L. (1985). Natural iodine-129 as an environmental tracer. Geochimica Et Cosmochimica Acta, 49(2), 337-347. 
Fan, Y.K., Zhou W.J., Hou X.L. (2018). Pre-nuclear level of ${ }^{129}$ I in Chinese loess-paleosol sections: A search for the natural ${ }^{129} \mathrm{I}$ level for dating in terrestrial environments. Geochim. Cosmochim. Acta, 231, 64-72.

Fehn, U., Snyder, G., \& Egeberg, P. K. (2000). Dating of pore waters with ${ }^{129}$ I: relevance for the origin of marine gas hydrates. Science, 289(5488), 2332.

Fehn, U., Holdren, G. R., Elmore, D., Brunelle, T., Teng, R., \& Kubik, P. W. (2013). Determination of natural and anthropogenic ${ }^{129} \mathrm{I}$ in marine sediments. Geophysical Research Letters, 13(2), 137-139.

Gibson, J. J., Birks, S. J., \& Yi, Y. (2016). Higher tritium concentrations measured in permafrost thaw lakes in northern Alberta. Hydrological Processes, 30(2), 245-249.

He, C., Hou, X., Zhao, Y., Wang, Z., Li, H., \& Chen, N., et al. (2011). ${ }^{129}$ I level in seawater near a nuclear power plant determined by accelerator mass spectrometer. Nuclear Instruments \& Methods in Physics Research, 632(1), 152-156.

He, P., Aldahan, A., Possnert, G., \& Hou, X. L. (2013). A summary of global ${ }^{129}$ I in marine waters. Nuclear Instruments \& Methods in Physics Research, 294, 537-541.

Herod, M. N., Li, T., Pellerin, A., Kieser, W. E., \& Clark, I. D. (2016). The seasonal fluctuations and accumulation of iodine-129 in relation to the hydrogeochemistry of the wolf creek research basin, a discontinuous permafrost watershed. Science of the Total Environment, 569-570, 1212-1223.

Hou, X. L., Dahlgaard, H., Nielsen, S. P., \& Ding, W. J. (2000). Iodine-129 in human thyroid and seaweed in China. Science of the Total Environment, 246(2-3), 285-291.

Hou, X. L., Dahlgaard, H., Nielsen, S. P., \& Kucera, J. (2002). Level and origin of iodine129 in the Baltic Sea. Journal of Environmental Radioactivity, 61(3), 331-343.

Hou, X. L., Fogh, C. L., Kucera, J., Andersson, K. G., Dahlgaard, H., \& Nielsen, S. P. (2003). Iodine-129 and caesium-137 in Chernobyl contaminated soil and their chemical fractionation. Science of the Total Environment, 308(1), 97-109.

Hou, X. L., Povinec, P. P., Zhang, L., Shi, K., Biddulph, D., \& Chang, C. C., et al. (2013). Iodine-129 in seawater offshore fukushima: distribution, inorganic speciation, sources, and budget. Environmental Science \& Technology, 47(7), 3091-8.

Jin, H. J., He, R. X., Cheng, G. D., Wu, Q. B., Wang, S. L., \& Chang, X. L. (2009). Changes in frozen ground in the source area of the yellow river on the Qinghai-Tibet plateau, 
China, and their eco-environmental impacts. Environmental Research Letters, 4(4), 045206.

Kilius, L. R., Litherland, A. E., Rucklidge, J. C., \& Baba, N. (1992). Accelerator massspectrometric measurements of heavy long-lived isotopes. International journal of radiation applications and instrumentation. Part A. Applied radiation and isotopes, 43(1-2), 279-287.

Kohman, T. P., \& Edwards, R. R. (1966). ${ }^{129} \mathrm{I}$ as a geochemical and ecological tracer. Progress Report, December 1, 1965-October 31, 1966 (No. NYO--3624-1). Carnegie Inst. of Tech., Pittsburgh, Pa. Dept. of Chemistry.

Li, B., Zhang, P. Q., Chen, C. Y., He, M., \& Chai, Z. F. (2005). Determination of ${ }^{129}$ I levels in Chinese biological and environmental specimens by accelerator mass spectrometry. Chinese Journal of Analytical Chemistry, 33(7), 904-908.

Liu, D., Hou, X., Du, J., Zhang, L., \& Zhou, W. (2016a). ${ }^{129}$ I and its species in the East China Sea: level, distribution, sources and tracing water masses exchange and movement. Scientific reports, 6, 36611 .

Liu, Z., Zhao, Y., Colin, C., Stattegger, K., Wiesner, M. G., \& Huh, C. A., et al. (2016b). Source-to-sink transport processes of fluvial sediments in the South China Sea. EarthScience Reviews, 153, 238-273.

Luo, M., Hou, X., Zhou, W., He, C., Chen, N., \& Liu, Q., et al. (2013). Speciation and migration of ${ }^{129} \mathrm{I}$ in soil profiles. Journal of Environmental Radioactivity, 118, 30.

Ma, X., Song, Y., Liu, S., Jiang, L., \& Hong, F. (2013). Origin and evolution of waters in the Hancheng coal seams, the Ordos Basin, as revealed from water chemistry and isotope (H, O, $\left.{ }^{129} \mathrm{I}\right)$ analyses. Science China Earth Sciences, 56(11), 1962-1970.

Michel, R., Daraoui, A., Gorny, M., Jakob, D., Sachse, R., \& Tosch, L., et al. (2012). Iodine-129 and iodine-127 in European seawaters and in precipitation from northern Germany. Science of the Total Environment, 419(3), 151-169.

Moran, J. E., Fehn, U., \& Teng, R. T. D. (1998). Variations in ${ }^{129} \mathrm{I}^{127} \mathrm{I}$ ratios in recent marine sediments: evidence for a fossil organic component. Chemical Geology, 152(1-2), 193-203.

Moran, J. E., Oktay, S. D., \& Santschi, P. H. (2002). Sources of iodine and iodine 129 in rivers. Water resources research, 38(8). 
454 Nagai, H., Hasegawa, A., Yamagata, T., Kumamoto, Y., Nishino, S., \& Matsuzaki, H. (2015). Anthropogenic ${ }^{129} \mathrm{I}$ in the North Pacific, Bering and Chukchi Seas, and Arctic Ocean in 2012-2013. Nuclear Inst \& Methods in Physics Research B, 361, 680-684.

Qu, T., Girton, J. B., \& Whitehead, J. A. (2006). Deepwater overflow through Luzon strait. Journal of Geophysical Research: Oceans, 111(C1).

Rao, U., \& Fehn, U. (1999). Sources and reservoirs of anthropogenic iodine-129 in western New York. Geochimica Et Cosmochimica Acta, 63(13-14), 1927-1938.

Reithmeier, H., Lazarev, V., Rühm, W., \& Nolte, E. (2010). Anthropogenic ${ }^{129}$ I in the atmosphere: overview over major sources, transport processes and deposition pattern. Science of the Total Environment, 408(21), 5052-5064.

Schink, D. R., Santschi, P. H., Corapcioglu, O., Sharma, P., \& Fehn, U. (1995). ${ }^{129}$ I in gulf of mexico waters. Earth \& Planetary Science Letters, 135(1-4), 131-138.

Schmidt, A., Schnabel, C., Handl, J., Jakob, D., Michel, R., \& Synal, H. A., et al. (1998). On the analysis of iodine-129 and iodine-127 in environmental materials by accelerator mass spectrometry and ion chromatography. Science of the Total Environment, 223(2-3), 131-156.

Snyder, G., \& Fehn, U. (2004). Global distribution of ${ }^{129}$ I in rivers and lakes: implications for iodine cycling in surface reservoirs. Nuclear Instruments \& Methods in Physics Research, 223-224, 579-586.

Snyder, G., Aldahan, A., \& Possnert, G. (2010). Global distribution and long-term fate of anthropogenic ${ }^{129} \mathrm{I}$ in marine and surface water reservoirs. Geochemistry Geophysics Geosystems, 11(4).

Suzuki, T., Minakawa, M., Amano, H., \& Togawa, O. (2010). The vertical profiles of iodine-129 in the Pacific Ocean and the japan sea before the routine operation of a new nuclear fuel reprocessing plant. Nuclear Instruments \& Methods in Physics Research, 268(7-8), 1229-1231.

Wang, G. X., Hu, H. C., \& Li, T. B. (2009). The influence of freeze-thaw cycles of active soil layer on surface runoff in a permafrost watershed. Journal of Hydrology, 375(3), 438-449.

Wang, G., Xie, S., Qu, T., \& Huang, R. X. (2011). Deep South China Sea circulation. Geophysical Research Letters, 38(5), 3115-3120. 
Watanabe, Y. W., Watanabe, S., \& Tsunogai, S. (1991). Tritium in the japan sea and the renewal time of the japan sea deep water. Marine Chemistry, 34(1-2), 97-108.

Yang, Y., Wu, Q., Yun, H., Jin, H., \& Zhang, Z. (2016). Evaluation of the hydrological contributions of permafrost to the thermokarst lakes on the Qinghai-Tibet Plateau using stable isotopes. Global and Planetary Change, 140, 1-8.

Zhang, L., Zhou, W., Hou, X., Chen, N., Liu, Q., \& He, C., et al. (2011). Level and source of ${ }^{129} \mathrm{I}$ of environmental samples in Xi'an region, China. Science of the total environment, 409(19), 3780-3788.

Zhang, H., Chen, Y., Hou, X., Sun, H., Lu, Y., \& Zhang, L. (2012). The distribution and source apportionment of ${ }^{129} \mathrm{I}$ in coastal seawater of Shenzhen Dapeng Peninsula. Journal of Shenzhen University Science \& Engineering, 29(1), 1-6 (in Chinese).

Zhang, R., Zhang, H., Hou, X., Chai, Z., Chen, Y., \& Fan, Y. (2014). ${ }^{129}$ I assessment reveals the impact of Fukushima incident on Dapeng Peninsula, Shenzhen, China. Journal of Radioanalytical and Nuclear Chemistry, 301(1), 57-63.

Zhang, L., Hou, X., \& Xu, S. (2016). Speciation of ${ }^{127} \mathrm{I}$ and ${ }^{129} \mathrm{I}$ in atmospheric aerosols at Risø, Denmark: insight into sources of iodine isotopes and their species transformations. Atmospheric Chemistry and Physics, 16(4), 1971-1985.

Zhou, W. J., Hou, X. L., Chen, N., Zhang, L. Y., Liu, Q., \& He, C. H., et al. (2010). Preliminary study of radioisotope ${ }^{129} \mathrm{I}$ application in China using Xi'an accelerator mass spectrometer. INCS News, 7(1), 8-23. 


\section{Figure captions}

521 Figure 1 Locations of sampling sites. Water samples reported in literature (Zhang et al., 2011) are marked by grey circles. The ${ }^{129}$ I concentrations in the samples are shown as the size of the circles.

524 Figure 2 Distributions of ${ }^{129}$ I concentrations in the water samples of rivers, lakes and springs in the source area of the Yellow River (SAYR), Qinghai-Tibet region. 
Table 1 Analytical results of ${ }^{127} \mathrm{I}$ and ${ }^{129} \mathrm{I}$ and ${ }^{129} \mathrm{I} /{ }^{127} \mathrm{I}$ of water samples collected from rivers, lake and springs in the Qinghai-Tibet region, Yangtze Estuary and South China Sea.

\begin{tabular}{|c|c|c|c|c|c|c|}
\hline \multirow[t]{2}{*}{$\begin{array}{c}\text { Sampling } \\
\text { ID }\end{array}$} & \multicolumn{2}{|c|}{ Sampling site } & \multirow{2}{*}{$\frac{\text { Depth }}{\mathrm{m}}$} & \multirow{2}{*}{$\frac{{ }^{127} \text { I concentration }}{\mu \mathrm{g} / \mathrm{L}}$} & \multirow{2}{*}{$\begin{array}{c}{ }^{129} \mathrm{I} \\
\text { concentration } \\
\times 10^{6} \text { atoms } / \mathrm{L}\end{array}$} & \multirow{2}{*}{$\frac{{ }^{129} \mathrm{I} /{ }^{127} \text { I ratio }}{\times 10^{-10}}$} \\
\hline & ${ }^{\circ} \mathrm{N}$ & ${ }^{\circ} \mathrm{E}$ & & & & \\
\hline \multicolumn{7}{|l|}{ River } \\
\hline 1 & $34^{\circ} 39^{\prime} 59.37^{\prime \prime}$ & $98^{\circ} 08^{\prime} 16.35^{\prime \prime}$ & & $14.3 \pm 0.2$ & $5.36 \pm 0.55$ & $0.792 \pm 0.082$ \\
\hline 2 & $34^{\circ} 52^{\prime} 21.94^{\prime \prime}$ & $98^{\circ} 11^{\prime} 16.93^{\prime \prime}$ & & $7.16 \pm 0.17$ & $25.0 \pm 1.9$ & $7.40 \pm 0.56$ \\
\hline 3 & $34^{\circ} 52^{\prime} 01.56^{\prime \prime}$ & $97^{\circ} 30^{\prime} 21.95^{\prime \prime}$ & & $7.81 \pm 0.19$ & $42.7 \pm 3.2$ & $11.6 \pm 0.9$ \\
\hline 4 & $34^{\circ} 19^{\prime} 33.13^{\prime \prime}$ & $97^{\circ} 55^{\prime} 28.19^{\prime \prime}$ & & $4.45 \pm 0.14$ & $27.0 \pm 1.7$ & $12.8 \pm 0.8$ \\
\hline 5 & $34^{\circ} 27^{\prime} 26.33^{\prime \prime}$ & $97^{\circ} 43^{\prime} 9.22^{\prime \prime}$ & & $2.28 \pm 0.07$ & $11.0 \pm 0.9$ & $10.6 \pm 0.9$ \\
\hline 6 & $35^{\circ} 06^{\prime} 34.66^{\prime \prime}$ & $97^{\circ} 49^{\prime} 55.29^{\prime \prime}$ & & $3.95 \pm 0.11$ & $36.4 \pm 0.9$ & $19.8 \pm 0.5$ \\
\hline \multicolumn{7}{|l|}{ Lake } \\
\hline 7 & $34^{\circ} 18^{\prime} 56.22^{\prime \prime}$ & $98^{\circ} 37^{\prime} 16.43^{\prime \prime}$ & & $6.17 \pm 0.15$ & $6.58 \pm 1.37$ & $2.26 \pm 0.44$ \\
\hline 8 & $34^{\circ} 51^{\prime} 22.61^{\prime \prime}$ & $98^{\circ} 07^{\prime} 51.63^{\prime \prime}$ & & $19.1 \pm 0.3$ & $2.04 \pm 0.26$ & $0.225 \pm 0.030$ \\
\hline 9 & $34^{\circ} 46^{\prime} 52.61^{\prime \prime}$ & $98^{\circ} 09^{\prime} 42.86^{\prime \prime}$ & & $7.58 \pm 0.19$ & $45.8 \pm 2.6$ & $12.8 \pm 0.7$ \\
\hline 10 & $33^{\circ} 54^{\prime} 38.79^{\prime \prime}$ & $102^{\circ} 49^{\prime} 1.15^{\prime \prime}$ & & $2.41 \pm 0.07$ & $8.21 \pm 0.76$ & $7.10 \pm 0.66$ \\
\hline 11 & $35^{\circ} 05^{\prime} 6.16^{\prime \prime}$ & $96^{\circ} 33^{\prime 2} 26.61^{\prime \prime}$ & & $2.18 \pm 0.06$ & $17.7 \pm 1.6$ & $16.9 \pm 1.5$ \\
\hline 12 & $36^{\circ} 33^{\prime} 15.98^{\prime \prime}$ & $100^{\circ} 39^{\prime} 1.38^{\prime \prime}$ & & $5.14 \pm 0.08$ & $51.2 \pm 1.5$ & $21.3 \pm 0.6$ \\
\hline \multicolumn{7}{|l|}{ Spring } \\
\hline 13 & $34^{\circ} 22^{\prime} 29.15^{\prime \prime}$ & $98^{\circ} 32^{\prime} 22.27^{\prime \prime}$ & & $5.17 \pm 0.14$ & $3.46 \pm 0.32$ & $1.41 \pm 0.13$ \\
\hline 14 & $35^{\circ} 24^{\prime} 16.69^{\prime \prime}$ & $99^{\circ} 25^{\prime} 47.95^{\prime \prime}$ & & $15.3 \pm 0.3$ & $1.26 \pm 0.21$ & $0.173 \pm 0.031$ \\
\hline 15 & $35^{\circ} 02^{\prime} 58.18^{\prime \prime}$ & $96^{\circ} 14^{\prime} 42.27^{\prime \prime}$ & & $4.28 \pm 0.10$ & $2.30 \pm 0.48$ & $1.13 \pm 0.23$ \\
\hline 16 & $35^{\circ} 16^{\prime} 13.88^{\prime \prime}$ & $96^{\circ} 44^{\prime} 43.33^{\prime \prime}$ & & $4.40 \pm 0.11$ & $4.34 \pm 0.33$ & $2.40 \pm 0.19$ \\
\hline \multicolumn{7}{|l|}{ Estuary } \\
\hline 17 & $32^{\circ} 48^{\prime} 0.00^{\prime \prime}$ & $122^{\circ} 14^{\prime} 44.99^{\prime \prime}$ & & $54.9 \pm 0.7$ & $21.1 \pm 0.8$ & $0.808 \pm 0.029$ \\
\hline
\end{tabular}




\begin{tabular}{|c|c|c|c|c|c|c|}
\hline 18 & $31^{\circ} 25^{\prime} 43.97^{\prime \prime}$ & $122^{\circ} 30^{\prime} 7.67^{\prime \prime}$ & & $46.1 \pm 0.7$ & $17.7 \pm 0.5$ & $0.810 \pm 0.023$ \\
\hline \multicolumn{7}{|c|}{ Seawater } \\
\hline 19 & $18^{\circ} 00^{\prime} 14.04^{\prime \prime}$ & $116^{\circ} 00^{\prime} 23.4^{\prime \prime}$ & 0 & $55.9 \pm 0.8$ & $12.1 \pm 0.6$ & $0.457 \pm 0.022$ \\
\hline 20 & $18^{\circ} 00^{\prime} 14.04^{\prime \prime}$ & $116^{\circ} 00^{\prime} 23.4^{\prime \prime}$ & 75 & $57.7 \pm 0.9$ & $14.1 \pm 0.4$ & $0.516 \pm 0.016$ \\
\hline 21 & $18^{\circ} 00^{\prime} 14.04^{\prime \prime}$ & $116^{\circ} 00^{\prime} 23.4^{\prime \prime}$ & 100 & $58.5 \pm 0.9$ & $12.0 \pm 0.3$ & $0.432 \pm 0.010$ \\
\hline 22 & $18^{\circ} 00^{\prime} 14.04^{\prime \prime}$ & $116^{\circ} 00^{\prime} 23.4^{\prime \prime}$ & 200 & $56.6 \pm 0.7$ & $11.1 \pm 0.3$ & $0.414 \pm 0.013$ \\
\hline 23 & $18^{\circ} 00^{\prime} 14.04^{\prime \prime}$ & $116^{\circ} 00^{\prime} 23.4^{\prime \prime}$ & 400 & $61.6 \pm 0.9$ & $15.4 \pm 1.3$ & $0.527 \pm 0.046$ \\
\hline 24 & $18^{\circ} 00^{\prime} 14.04^{\prime \prime}$ & $116^{\circ} 00^{\prime} 23.4^{\prime \prime}$ & 1000 & $64.2 \pm 0.9$ & $13.5 \pm 0.6$ & $0.443 \pm 0.019$ \\
\hline 25 & $18^{\circ} 00^{\prime} 14.04^{\prime \prime}$ & $116^{\circ} 00^{\prime} 23.4^{\prime \prime}$ & 1500 & $68.6 \pm 0.9$ & $7.15 \pm 0.25$ & $0.220 \pm 0.008$ \\
\hline 26 & $18^{\circ} 00^{\prime} 14.04^{\prime \prime}$ & $116^{\circ} 00^{\prime} 23.4^{\prime \prime}$ & 2000 & $68.6 \pm 1.0$ & $1.20 \pm 0.14$ & $0.037 \pm 0.005$ \\
\hline 27 & $18^{\circ} 00^{\prime} 14.04^{\prime \prime}$ & $116^{\circ} 00^{\prime} 23.4^{\prime \prime}$ & 3000 & $65.8 \pm 0.9$ & $3.16 \pm 0.16$ & $0.101 \pm 0.006$ \\
\hline 28 & $18^{\circ} 00^{\prime} 14.04^{\prime \prime}$ & $116^{\circ} 00^{\prime} 23.4^{\prime \prime}$ & 3800 & $66.3 \pm 1.0$ & $0.992 \pm 0.110$ & $0.0315 \pm 0.0034$ \\
\hline
\end{tabular}



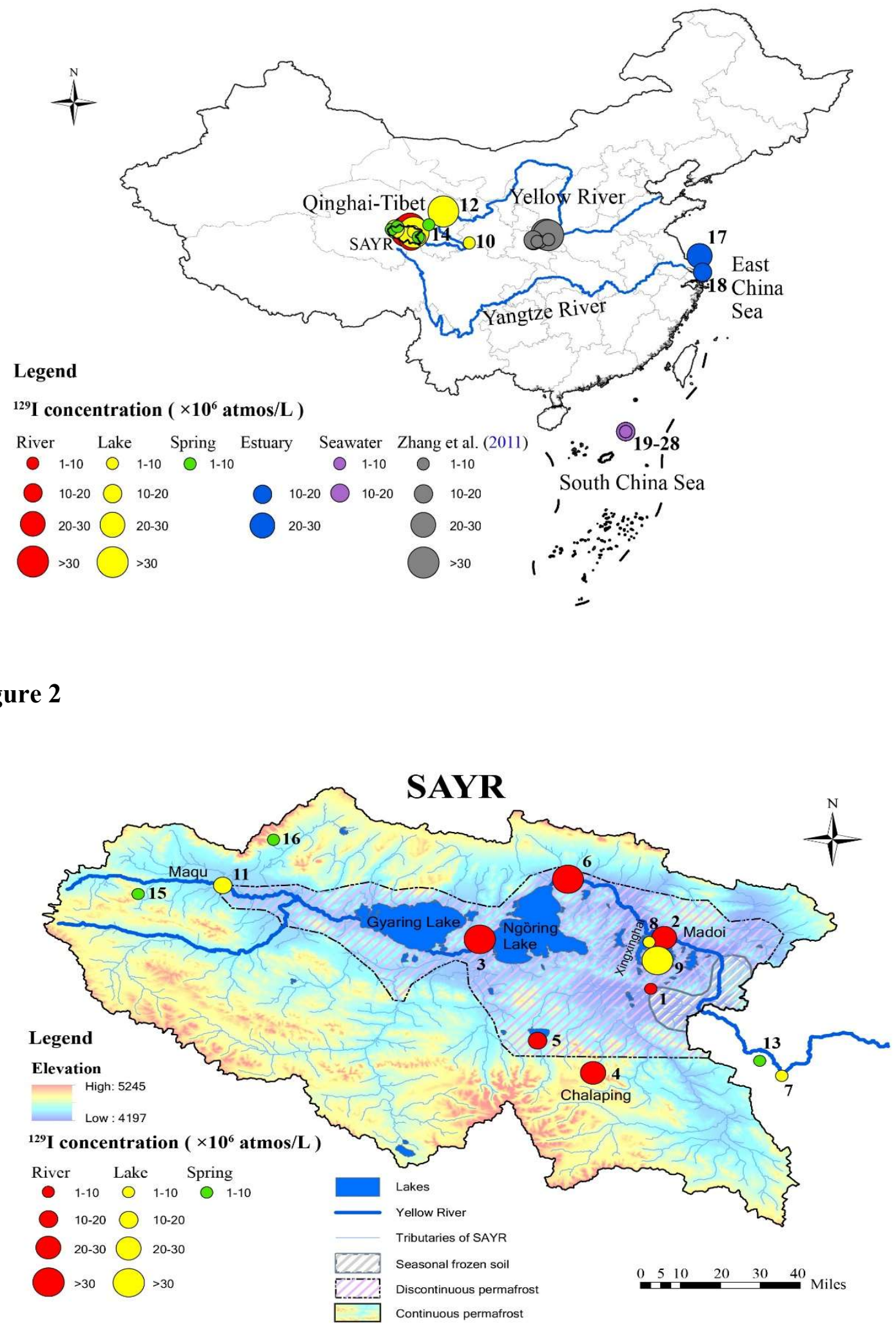
$6 \quad$ Figure 3

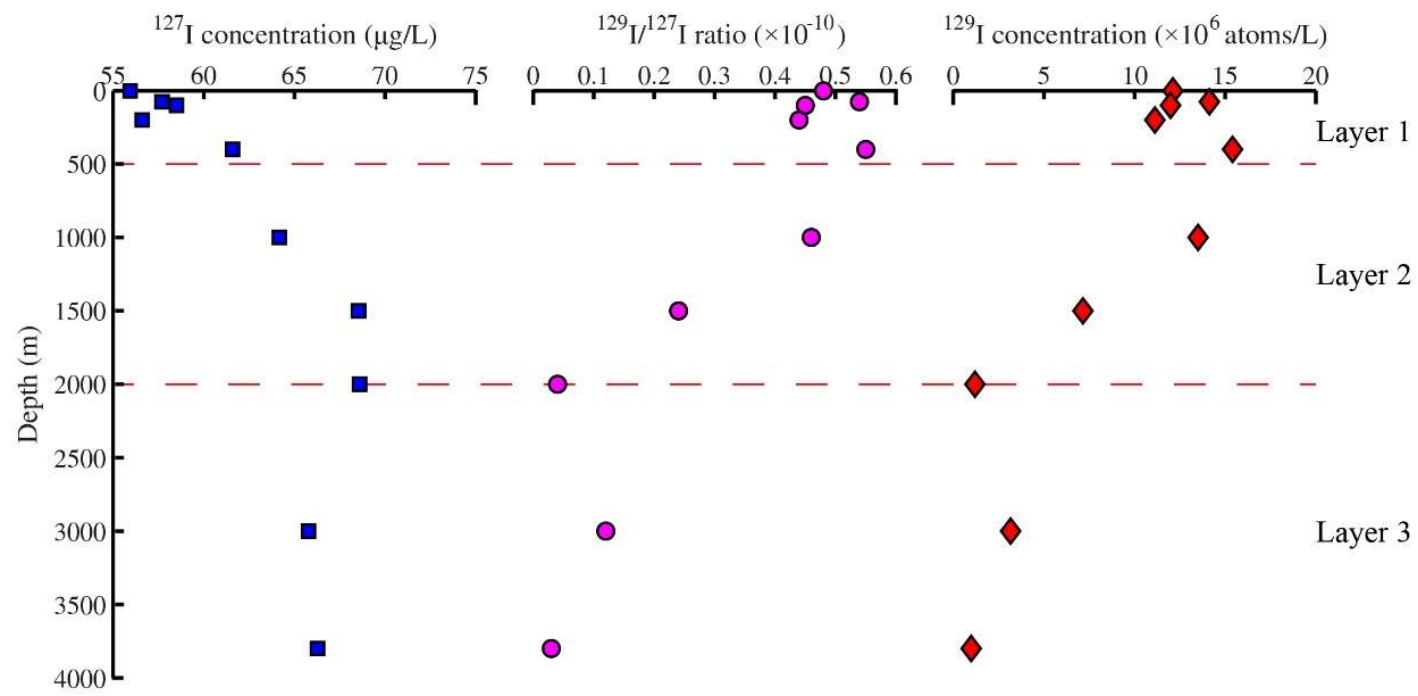

(a)

(b)

(c)

Figure 4
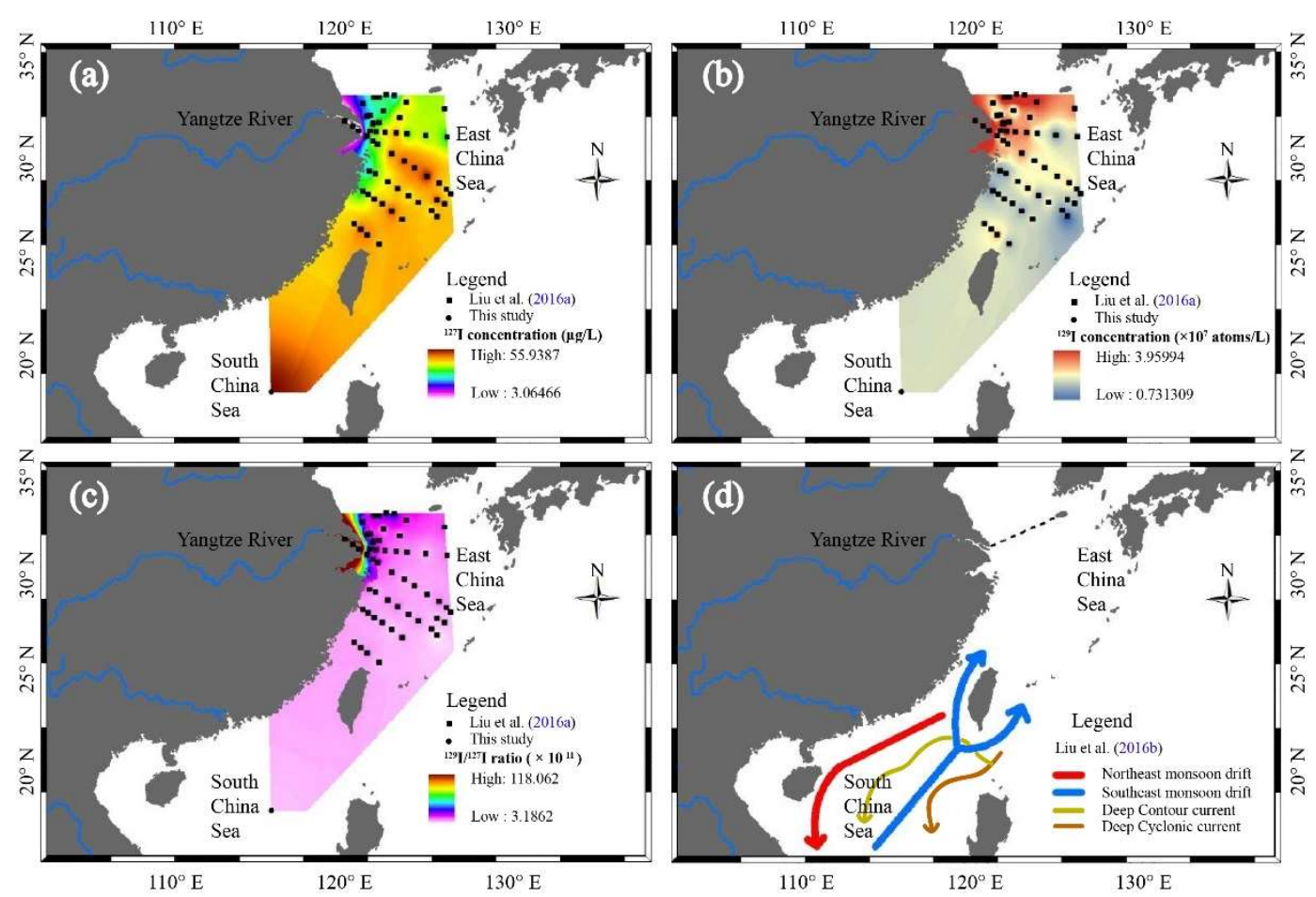


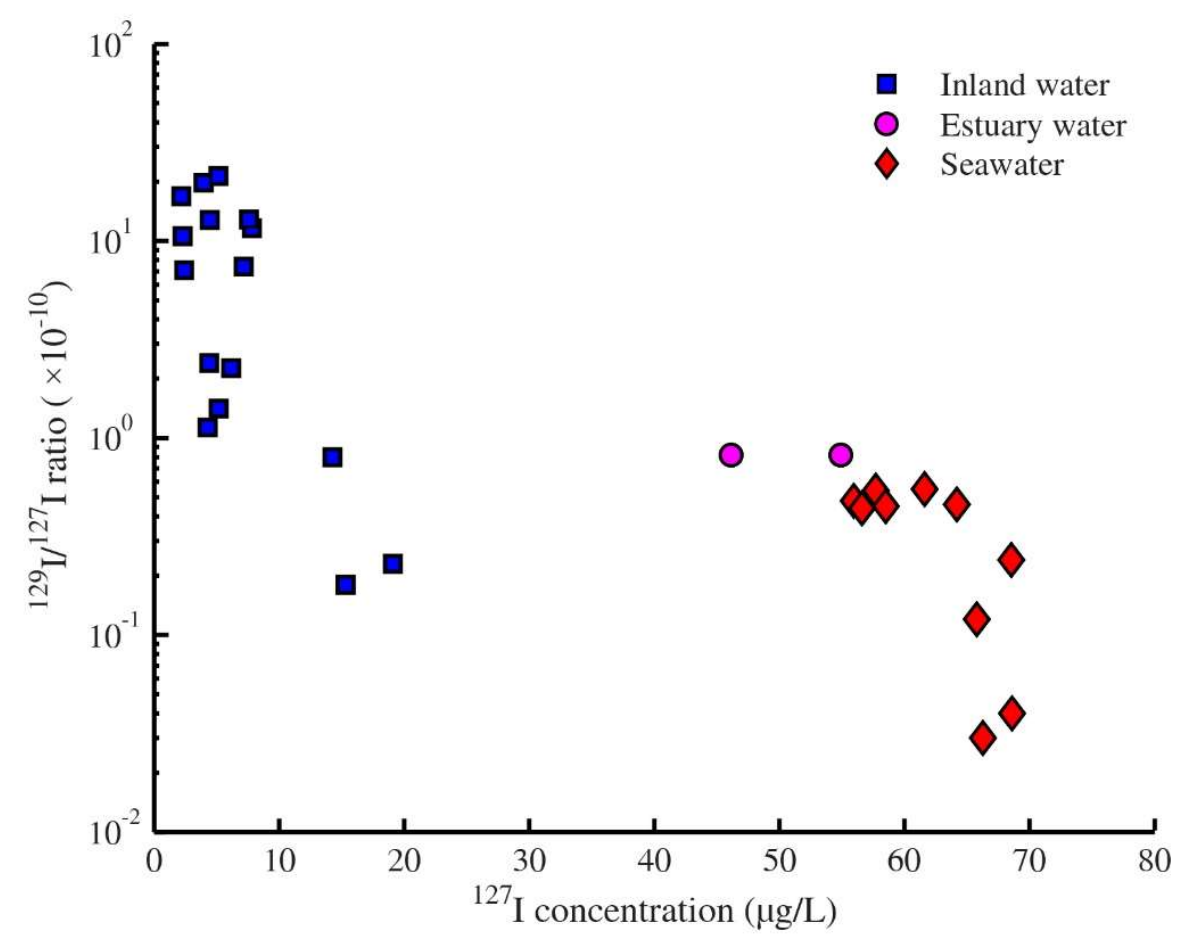

13

14

\section{$15 \quad$ Figure 6}
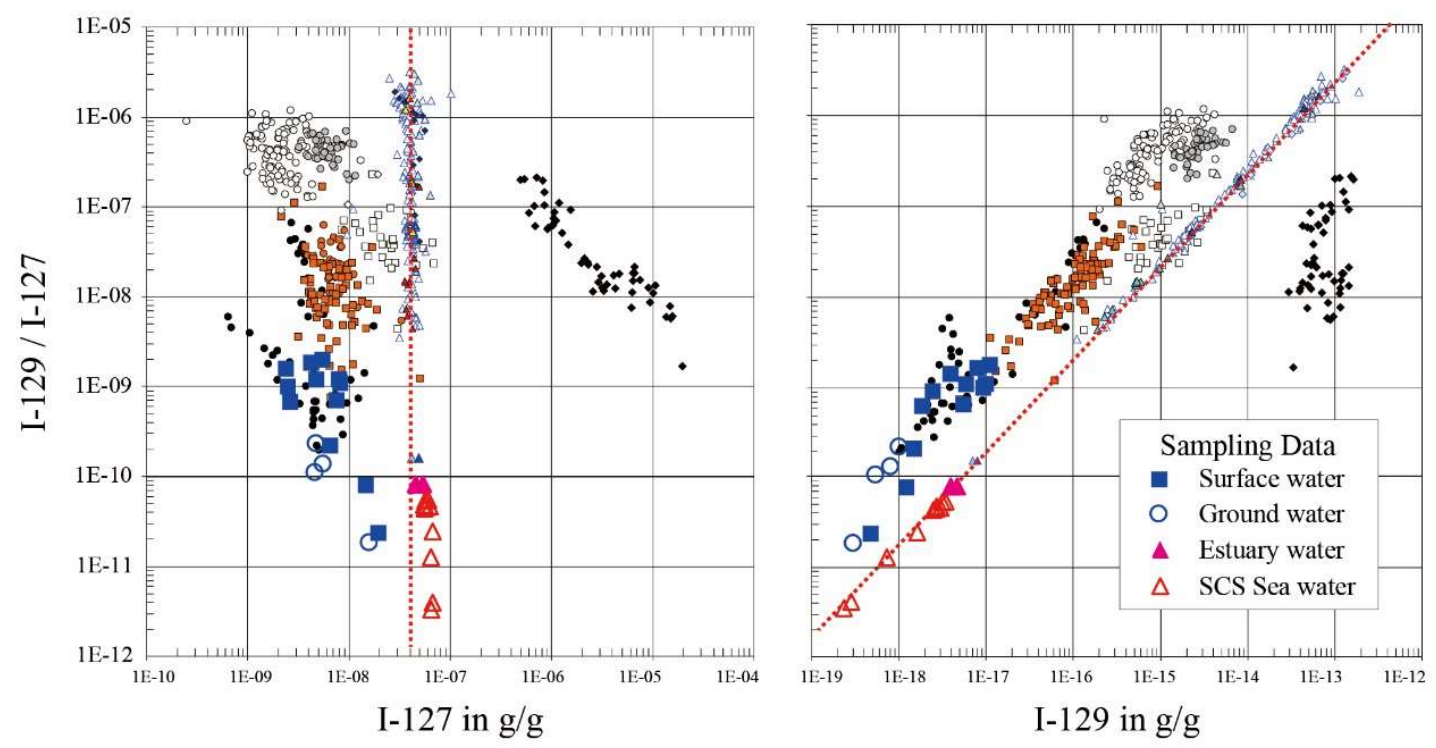

16

17 


\section{$19 \quad$ Figure 7}

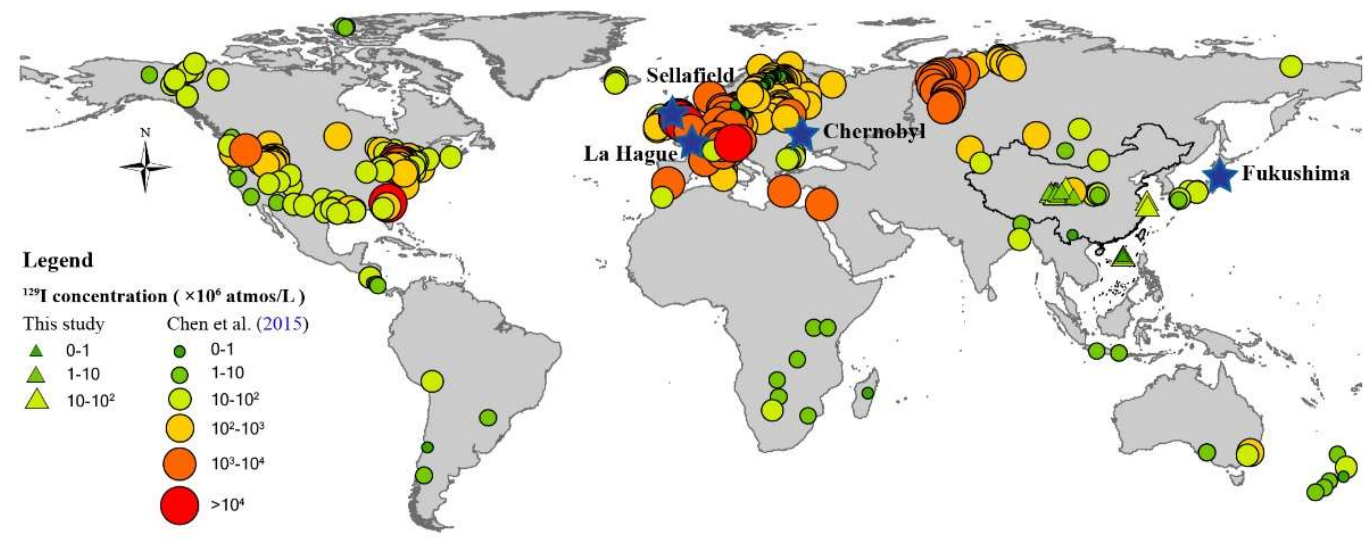

